\title{
Suppression of Shade- or Heat-induced Leaf Senescence in Creeping Bentgrass through Transformation with the ipt Gene for Cytokinin Synthesis
}

\author{
Jinpeng Xing, Yan Xu, Jiang Tian, Thomas Gianfagna, and Bingru Huang ${ }^{\mathbf{1}}$ \\ Department of Plant Biology and Pathology, Rutgers University, New Brunswick, NJ 08901
}

\begin{abstract}
ADDITIONAL INDEX WORDS. high temperature, darkness, chlorophyll, isopentenyl transferase, Agrostis stolonifera, SAG12-ipt, HSP18-ipt

Abstract. Cytokinins have been associated with delaying or suppressing leaf senescence in plants. The objectives of this study were to determine whether the expression of the ipt gene that encodes adenine isopentenyltransferase would delay leaf senescence induced by shade or heat stress in a perennial grass species. Creeping bentgrass (Agrostis stolonifera cv. Penncross) was transformed with ipt isolated from agrobacterium (Agrobacterium tumefaciens) using two gene constructs (SAG12-ipt and HSP18-ipt) designed to activate cytokinin synthesis during shade or heat stress. Whole plants of nine $S A G 12$-ipt transgenic lines and the nontransgenic control plants were incubated in darkness at $20^{\circ} \mathrm{C}$ for 20 days. Chlorophyll content of all transgenic lines and the control line decreased after dark treatment, but the decline was less pronounced in transgenic lines. All transgenic lines had higher isopentenyladenine (iP/iPA) content than the control line after 20 days of treatment. In six of the transgenic lines, iP/iPA content remained the same or higher after dark treatment. Whole plants of nine HSP18-ipt transgenic lines and the control plants were incubated at $35^{\circ} \mathrm{C}$ for 7 days. Chlorophyll and iP/iPA content declined in the control plants, but the nine transgenic lines had a significantly higher concentration of iP/iPA and were able to maintain chlorophyll content at the prestress level. Our results suggest that expression of $S A G 12$-ipt or $H S P 18$-ipt in creeping bentgrass resulted in increases in cytokinin production, which may have led to the delay and suppression of leaf senescence induced by shade or heat stress.
\end{abstract}

Naturally occurring and environmentally induced leaf senescence limits whole-plant photosynthetic capacity and plant productivity, as well as the aesthetic value of horticultural plants. Leaf senescence is characterized by yellowing or chlorosis of leaves as chlorophyll and other cellular components (e.g., proteins and nucleic acids) are degraded during natural or stress-induced leaf aging. Cytokinins (CK) have been well known for delaying leaf senescence, and in some cases, reversing this process (Gan and Amasino, 1996). Moreover, there is generally an inverse correlation between CK content and the severity of leaf senescence (Hare et al., 1997).

One approach to prevent or delay leaf senescence is to increase CK in leaves through the application of products containing CK, or to overexpress genes controlling CK synthesis through genetic transformation. Transgenic plants with modified endogenous CK production have recently been used to study the involvement of CK in delaying leaf senescence, using the gene encoding adenine isopentenyltransferase (ipt) isolated from agrobacterium. The ipt gene catalyzes the key step in de novo CK biosynthesis: the formation of $\mathrm{N}^{6}-\left(\Delta^{2}\right.$-isopentenyl) adenosine-5' -monophosphate from $\Delta^{2}$-isopentenyl pyrophosphate and s-adenosine-5'-monophosphate (Medford et al., 1989). This gene has been introduced into various plant species, mostly dicotyledonous plants, such as tobacco (Nicotiana tabacum)

Received for publication 9 Sept. 2009. Accepted for publication 1 Dec. 2009. We wish to thank the Center for Turfgrass Science, Rutgers University, for funding support of this research project.

We also thank Emily Merewitz and Dr. Chenpign Xu for reviewing the manuscript.

${ }^{1}$ Corresponding author. E-mail: huang@aesop.rutgers.edu.
(Gan and Amasino, 1996), cauliflower (Brassica oleracea var. botrytis) (Nguyen et al., 1998), lettuce (Lactuca sativa) (McCabe et al., 1998; McCabe et al., 2001), arabidopsis (Arabidopsis thaliana) (Huynh et al., 2005), petunia (Petunia Xhybrida) (Chang et al., 2003; Clark et al., 2004; Khodakovskaya et al., 2005), chrysanthemum (Dendranthema $\times$ grandiflorum) (Khodakovskaya et al., 2005), and tomato (Solanum lycopersicum) (Luo et al., 2005), and in a limited number of monocot plant species such as tall fescue (Festuca arundinacea) (Hu et al., 2005) and wheat (Triticum aestivum) (Sykorova et al., 2008). Most studies have confirmed that increases in endogenous production of CK delayed leaf senescence. However, some plants transformed with a high-expression ipt gene construct driven by constitutive promoters exhibit phenotypic signs of hormone surplus and growth abnormalities, such as dwarfism and limited root growth, due to overproduction of CK (Hewelt et al., 1994; Schmülling et al., 1989; Smigocki, 1991).

The expression of the ipt gene controlled by regulatable or inducible promoters prevents the problems associated with the overproduction of $\mathrm{CK}$ in transgenic plants with constitutive promoters. A senescence-activated promoter, $S A G 12$, was isolated from arabidopsis to drive ipt expression to delay leaf senescence (Gan and Amasino, 1995). The SAG12-ipt construct has an autoregulatory feature: the transcription of ipt is activated by SAG12 at the onset of leaf senescence, leading to the production of functional enzyme and CK production, which in turn delays senescence; when there are no longer senescence signals, the SAG12 promoter attenuates ipt transcription and subsequent enzyme production, thus providing autoregulatory control of CK synthesis (Gan and Amasino, 1995, 1996). Similarly, Rivero et al. (2007) used the promoter from a senescence-associated 
receptor protein kinase gene $(S A R K)$ as a promoter for ipt. Expression of $S A R K$-ipt resulted in delayed drought-induced leaf senescence in tobacco. Another class of commonly used promoters are those regulated by heat shock. In response to elevated temperatures, the synthesis of a family of protective proteins, named heat shock proteins (HSP), is induced. Transgenic plants of various species using heat shock promoters to control ipt gene transcription (HSP-ipt) have been created that increase $\mathrm{CK}$ synthesis and reduce leaf senescence under high temperature stress (Medford et al., 1989; Schmülling et al., 1989; Smart et al., 1991; Smigocki, 1991; Van Loven et al., 1993).

Leaf senescence is a major concern in turfgrass management because it not only negatively affects plant growth, but also the aesthetic turf quality. Turf quality often declines due to leaf senescence induced under environmental stresses such as shading and high temperature (Huang, 2004; Koh et al., 2003). Preventing or delaying leaf senescence is an effective approach to improve turf quality, especially in unfavorable environments. However, how ipt controlling $\mathrm{CK}$ synthesis may affect shade- or heat-induced leaf senescence has not been examined in turfgrass species. Using an agrobacteriummediated transformation technique, reporter genes or other target genes have been successfully transferred into several turfgrass species, including creeping bentgrass (Dong and Qu, 2005; Yu et al., 2000). With an aim to investigate whether activation of the ipt gene would delay leaf senescence in cool-season grass species exposed to shade or heat stress, we transformed cool-season creeping bentgrass, a widely used turfgrass species, using an agrobacterium-mediated transformation technique with two constructs: SAG12-ipt and HSP18-ipt. The expression pattern of SAG12-ipt and HSP18-ipt induced by shade or heat stress was examined, and leaf senescence and CK production associated with ipt gene expression were evaluated.

\section{Materials and Methods}

Tissue CUlture AND Plant Regeneration. Stolons of creeping bentgrass (cv. Penncross) were collected from a single plant for tissue culture to generate transgenic plants with identical genetic background. Stolons were cut to pieces and treated with $95 \%$ alcohol for $1 \mathrm{~min}$, followed by $15 \%$ household bleach (6.15\% sodium hypochlorite) for $5 \mathrm{~min}$, and washed with sterile water (five times) before placing in tissue culture medium. Calluses were produced in darkness at $24{ }^{\circ} \mathrm{C}$ on a tissue culture medium containing 4.3 g Murashige and Skoog (MS) salts and vitamins (Murashige and Skoog, 1962), $500 \mathrm{mg}$ of casein hydrolysate, $100 \mathrm{mg}$ of myoinositol, $6.6 \mathrm{mg}$ of dicamba, 2.5 $\mathrm{mg}$ of benzyladenine (BA) (Sigma-Aldrich, St. Louis), $30 \mathrm{~g}$ of sucrose, and $2 \mathrm{~g}$ of Gell-Gro (Pseudomonas elodea; ICN Biomedicals, Irvine, CA) in $1 \mathrm{~L}$ of water at $\mathrm{pH}$ 5.7. Calluses were formed and ready for transformation after 1 month of culture.

Plantlets were generated from calluses by transferring to the regeneration medium [RM (4.3 g of MS base, $100 \mathrm{mg}$ of myoinositol, 4 $\mathrm{mg}$ of BA, $20 \mathrm{~g}$ of sucrose, and $2.0 \mathrm{~g}$ of Gell-Gro in $1 \mathrm{~L}$ water at $\mathrm{pH}$ 5.8)] in a controlled chamber at $24{ }^{\circ} \mathrm{C}$, with a 12-h photoperiod, and 85 $\mu \mathrm{mol} \cdot \mathrm{m}^{-2} \cdot \mathrm{s}^{-1}$ photosynthetic photon flux (PPF; 400-700 nm). Emerging plantlets were subcultured at 2-week intervals. Seedlings with about five tillers each were transplanted into containers filled with soil and were kept in a greenhouse with a mean day/night temperature of $24 / 18^{\circ} \mathrm{C}$, with a $12 / 12$-h light/dark photoperiod, and light intensity ranging from 500 to $1000 \mu \mathrm{mol} \cdot \mathrm{m}^{-2} \cdot \mathrm{s}^{-1}$.

Plasmid construction. Two inducible promoters from arabidopsis, SAG12 and HSP18, were used in the plasmid constructs to introduce the ipt gene into creeping bentgrass. The senescence-specific $S A G 12$ promoter was used to drive the expression of the ipt gene at the onset of leaf senescence (Gan and Amasino, 1995). HSP18, a heat-inducible promoter, drives the expression of ipt when exposed to heat stress (Takahashi and Komeda, 1989). The ipt gene is from the Ti plasmid of agrobacterium. The construct pCAMBIA1300-SAG12-ipt was created from pSG516 (provided by R. Amasino, University of Wisconsin) and pCAMBIA 1300 (CAMBIA, Canberra, Australia), a binary plasmid containing the gene for hygromycin resistance. pSG516 contains the SAG12 promoter, ipt gene, and NOS ending region. pSG516 was cut with SpeI and the target fragment was inserted into pCAMBIA 1300 at the $X b a \mathrm{I}$ site to create pCAMBIA1300-SAG12-ipt (Fig. 1A).

The construct pCAMBIA1301-HSP18-ipt-GUS was created from pUC-HSP18, pSG516, and pCAMBIA 1301 (GenBank accession no. 234297), a binary plasmid containing the genes for hygromycin and $\beta$-glucuronidase (GUS). pUC-HSP18 was cut by NotI and NcoI to release the HSP 18 promoter $(0.7 \mathrm{~kb})$. pSG516 $(5.88 \mathrm{~kb})$ was also cut with NotI and NcoI to release the $S A G 12$ promoter $(2.2 \mathrm{~kb})$. The $3.68-\mathrm{kb}$ fragment containing ipt$N O S$ was ligated to the HSP 18 promoter to create a new plasmid pJP101 (4.38 kb) containing HSP18-ipt-NOS. pJP101 was cut with HindIII and $X b a \mathrm{I}$ and the HSP18-ipt-NOS fragment was inserted into the multicloning site of pCAMBIA1301 to create pCAMBIA1301-HSP18-ipt-GUS plasmid (Fig. 1B). Control lines were created using the empty vector.

AgrobaCterium-Mediated CREEPING BENTGRASS TRANSFORMATION. Agrobacterium LBA 4404 was transformed by electroporation at $2400 \mathrm{mV}$ using the constructs described above and empty vector control plasmids, and was grown at $28{ }^{\circ} \mathrm{C}$ for $2 \mathrm{~d}$. Agrobacterium LBA 4404 carrying the plasmid constructs was grown in Lysogeny broth (LB) medium supplemented with $50 \mathrm{mg} \cdot \mathrm{L}^{-1}$ kanamycin, $50 \mathrm{mg} \cdot \mathrm{L}^{-1}$ spectinomycin, and $50 \mu \mathrm{m}$ acetosyringone on a platform shaker $\left(28^{\circ} \mathrm{C}, 200 \mathrm{rpm}\right.$, and $48 \mathrm{~h}$ ). Agrobacterium culture was collected by centrifugation (at $2236 g_{n}$ for $10 \mathrm{~min}$ ) and resuspended to $\mathrm{OD}_{600}$ of 0.2 in a liquid coculture medium [LCM, a Phytagel-free callus induction medium with addition of $50 \mu \mathrm{M}$ acetosyringone and modified carbohydrate source (10 g. $\mathrm{L}^{-1}$ sucrose and $20 \mathrm{~g} \cdot \mathrm{L}^{-1}$ glucose)]. Embryogenic calluses, $\approx 40$-d-old and pretreated with $50 \mu \mathrm{M}$ acetosyringone, were cocultured with agrobacterium cell suspension for $30 \mathrm{~min}$ at room temperature. The agrobacterium-infected

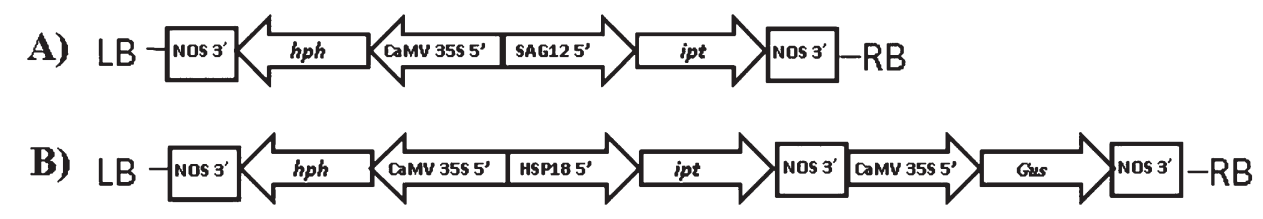

Fig. 1. Schematic diagram of plasmid constructs. (A) pCAMBIA1300-SAG12-ipt and (B) pCAMBIA1301HSP18-ipt-GUS; LB $=$ T-DNA left border, $\mathrm{RB}=\mathrm{T}$-DNA right border, $\mathrm{SAG12}=$ arabidopsis senescenceactivated promoter $12, \mathrm{ipt}=$ isopentenyladenine transferase gene, CaMV $35 \mathrm{~S}=$ cauliflower mosaic virus $35 \mathrm{~S}$ promoter, Hph = hygromycin phosphotransferase gene, CaMV 35S $3^{\prime}=3^{\prime}$ untranscribed region of the nopaline synthase gene, HSP18 = arabidopsis heat shock 18 promoter, Gus $=\beta$-glucuronidase (uidA) gene.

J. Amer. Soc. Hort. Sci. 134(6):602-609. 2009. 
calluses were cocultured on tissue culture medium with the addition of cefotaxime $\left(250 \mathrm{mg} \cdot \mathrm{L}^{-1}\right)$ for 1 week and were then transferred to a selection medium with the addition of hygromycin $\left(175 \mathrm{mg} \cdot \mathrm{L}^{-1}\right)$. Healthy calluses were then moved to regeneration medium. Regenerated seedlings were grown on media containing hygromycin $\left(175 \mathrm{mg} \cdot \mathrm{L}^{-1}\right)$ and those that survived antibiotic screening were considered to be hyg B-resistant plants and were selected for further analysis.

Polymerase Chain Reaction (PCR) analysis. Transformation was confirmed using PCR analysis. One 2-cm-long fresh grass leaf was collected from each line of the transgenic plants. The leaves were treated with $100 \mu \mathrm{L}$ of $0.4 \mathrm{M} \mathrm{NaOH}$ at $100^{\circ} \mathrm{C}$ for $5 \mathrm{~min}$, followed by $100 \mu \mathrm{L}$ of $0.5 \mathrm{M}$ Tris- $\mathrm{HCl}$ at $\mathrm{pH}$ of 8.0 and 100 $\mu \mathrm{L}$ of $0.4 \mathrm{M} \mathrm{HCl}$. A $2-\mu \mathrm{L}$ aliquot of the above solution was used as a template for PCR. A 50- $\mu \mathrm{L}$ PCR reaction solution was prepared, containing $10 \mathrm{~mm}$ Tris- $\mathrm{HCl}$ at $\mathrm{pH} 8.3,50 \mathrm{~mm} \mathrm{KCl}, 1.5 \mathrm{~mm}$ $\mathrm{MgCl}_{2}, 0.4 \mathrm{~mm}$ dNTP, $2 \mu \mathrm{L}$ of DNA template, 1 unit of Taq DNA polymerase, and $0.2 \mu \mathrm{M}$ primers $\left(5^{\prime}\right.$-GACCTGCATCTAA TTTTCGGTCCAAC-3' / ' ' -GGGGTGCAACATCTGCTTAAC TCT- $\left.3^{\prime}\right)$. The ipt gene-specific primers were designed based on the 723-bp agrobacterium ipt complete sequence (gi|;10955016:7864-8586) using primer3 (Invitrogen, Carlsbad, CA). Reaction conditions were: $94{ }^{\circ} \mathrm{C}$ for $1 \mathrm{~min}$ ( 1 cycle), then $94^{\circ} \mathrm{C}$ for $30 \mathrm{~s}, 60^{\circ} \mathrm{C}$ for $1 \mathrm{~min}, 72^{\circ} \mathrm{C}$ for $1 \mathrm{~min}(35$ cycles $), 72^{\circ} \mathrm{C}$ for $10 \mathrm{~min}$, and were then kept at room temperature to generate a 432-bp fragment

GUS STAINING. Histochemical staining for GUS activity was performed following the protocol described in Jefferson et al. (1987). The solution contained $0.01 \mathrm{M} \mathrm{NaH}_{2} \mathrm{PO}_{4}, 0.005 \mathrm{M}$ EDTA, $0.05 \mathrm{~mm} \mathrm{~K}_{3} \mathrm{FeCN}_{6}$ and $\mathrm{K}_{4} \mathrm{FeCN}_{6}$, and $0.1 \mathrm{mg} \cdot \mathrm{mL}^{-1} \mathrm{X}$ glucuronide. Root tissues were incubated in GUS staining solution for $6 \mathrm{~h}$ or overnight at $37^{\circ} \mathrm{C}$ and washed with water. Leaf tissues were removed with $75 \%$ ethanol for $3 \mathrm{~h}$ followed by $95 \%$ ethanol for $3 \mathrm{~h}$ and $100 \%$ ethanol overnight. After bleaching, tissue was washed in water for $1 \mathrm{~h}$.

SOUTHERN BLOT ANALYSIS OF TRANSGENE COPY NUMBERS. Selected transgenic lines were tested for copy number of ipt. Genomic DNA was extracted from leaf tissues using the maize (Zea mays) miniprep method (Dellaporta et al., 1983). The genomic size of creeping bentgrass is $2769 \mathrm{Mbp}$ per cell. The construct was about $13.5 \mathrm{~kb}$ in size. The ratio of genomic size to construct size was about 205000:1. For Southern blot analysis, $5 \mu \mathrm{g}$ of genomic DNA, $0.025 \mathrm{ng}$ of construct plasmid DNA ( 1 copy), $0.050 \mathrm{ng}$ of construct plasmid DNA ( 2 copy), $0.075 \mathrm{ng}$ of construct plasmid DNA (3 copy), $0.100 \mathrm{ng}$ of construct plasmid DNA (4 copy), $0.125 \mathrm{ng}$ of construct plasmid DNA (5 copy), and $0.150 \mathrm{ng}$ of construct plasmid DNA (6 copy) were loaded onto Hybond $\mathrm{N}^{+}$membranes (GE Healthcare, Piscataway, NJ). The coding region of ipt gene was radioactively labeled with $\alpha-{ }^{32} \mathrm{P}-\mathrm{dCTP}$ by using the random primer labeling system (Promega, Madison, WI) and was purified by MicroSpin $^{\text {TM }}$ G-50 Columns (GE Healthcare). Prehybridization and hybridization were carried out in $50 \%(\mathrm{v} / \mathrm{v})$ formamide, $5 \times$ SSPE, 10× Denhardt's, 1\% SDS, and herring sperm DNA (300 $\mathrm{mg} \cdot \mathrm{L}^{-1}$ ) in a total volume of $15 \mathrm{~mL}$ at $42{ }^{\circ} \mathrm{C}$ overnight. Washes were performed in $2 \times \mathrm{SSPE}$ and $1 \% \mathrm{SDS}$ for $25 \mathrm{~min}$ at room temperature and in three additional steps with preheated $0.2 \times$ SSPE and $0.2 \% \mathrm{SDS}$ at $65^{\circ} \mathrm{C}$ for 5 to $20 \mathrm{~min}$. The membranes were exposed to X-Ray film at $-70{ }^{\circ} \mathrm{C}$ for $3 \mathrm{~d}$.

RNA ISOLATION AND NORTHERN BLOT. RNA was isolated by a miniprep procedure (Ausubel et al., 1995). Briefly, about $3 \mathrm{~g}$ of leaves were ground in liquid $\mathrm{N}_{2}$ in a mortar with pestle. The ground tissue was added to a tube containing $5 \mathrm{~mL}$ of watersaturated phenol and $5 \mathrm{~mL}$ of preheated $\left(80^{\circ} \mathrm{C}\right)$ RNA extraction buffer (200 mm Tris-HCl, pH 8.0, 100 mm LiCl, 20 mм EDTA, and $1 \% \mathrm{SDS}$ ) and was vortexed. One-half volume chloroform: isoamyl alcohol (24:1) was added and the sample was vortexed again. After centrifugation, the upper aqueous phase was removed to a new tube and 1 volume of $4 \mathrm{M} \mathrm{LiCl}$ was added, mixed well, and placed at $-70{ }^{\circ} \mathrm{C}$ for $1 \mathrm{~h}$. The sample was centrifuged for $15 \mathrm{~min}$. The pellet was then washed in DEPCtreated $70 \%$ ethanol, air dried, and resuspended in $500 \mu \mathrm{L}$ of DEPC-treated water.

RNA samples $(10 \mu \mathrm{g})$ were separated on $1.2 \%$ formaldehyde agarose gels and transferred to membranes (Magnacharge nylon Membrane; BioWorld, Dublin, $\mathrm{OH})$. RNA blots were hybridized with the probe containing the coding region (520 bp) of the ipt gene that was labeled by a random primer labeling kit (Prime-a-Gene kit, Promega) with ${ }^{32} \mathrm{P}-\mathrm{dCTP}$. Northern blots were hybridized at $65^{\circ} \mathrm{C}$ for $24 \mathrm{~h}$ in $2 \times \mathrm{SSPE}$, SDS, PEG 8000, and heparin (Sigma-Aldrich). Denatured herring sperm DNA $\left(0.2 \mathrm{mg} \cdot \mathrm{mL}^{-1}\right)$ was added to the denatured, labeled probe and the solution was diluted to a final concentration of 106 counts per minute per milliliter for hybridization. RNA membranes were washed twice in $2 \times \mathrm{SSC}$ and $0.1 \% \mathrm{SDS}$ for $40 \mathrm{~min}$, and twice in $0.5 \times \mathrm{SSC}$ and $0.1 \% \mathrm{SDS}$ for $40 \mathrm{~min}$. The membranes were exposed to X-Ray film at $-70{ }^{\circ} \mathrm{C}$ for 3 to $7 \mathrm{~d}$.

CHARACTERIZATION OF EXPRESSION PATTERN OF HSP18-IPT AND $\boldsymbol{S A G 1 2 - I P T}$. The expression pattern of the HSP18 promoter in creeping bentgrass in response to increasing temperatures and treatment durations was examined. For time courses, excised leaves or whole plants of HSP18-ipt transgenic lines were exposed to $35^{\circ} \mathrm{C}$ in a growth chamber for 2,4 , and $12 \mathrm{~h}$. Leaf samples were collected for Northern blot analysis. For temperature courses, excised leaves or whole plants of HSP18ipt transgenic lines were exposed to $20,25,30,35$, and $40{ }^{\circ} \mathrm{C}$ for $2 \mathrm{~h}$ in growth chambers, and leaf samples were then collected for Northern blot analysis as described above.

The expression pattern of SAG12-ipt during dark- or heatinduced leaf senescence was evaluated for selected transgenic lines. Whole plants were exposed to light $\left(500 \mu \mathrm{mol} \cdot \mathrm{m}^{-2} \cdot \mathrm{s}^{-1}\right)$ at $20{ }^{\circ} \mathrm{C}$ (control), dark at $20^{\circ} \mathrm{C}$ (shade), or light at $35^{\circ} \mathrm{C}$ (heat stress) for $7 \mathrm{~d}$ in a growth chamber. Leaf samples were collected for Northern blot analysis as described above.

EVALUATION OF LEAF SENESCENCE AND QUANTIFICATION OF CK Production. Nine transgenic lines of SAG12-ipt and HSP18-ipt transformants that exhibited desirable turf phenotypic traits (fine leaf texture and uniform green leaves) were selected for the physiological evaluation.

Detached leaves and intact plants of SA G12-ipt or HSP18-ipt transgenic plants were used to determine whether transgenic plants exhibit delayed leaf senescence induced by dark or heat stress in comparison with the control line (transformed with the empty vector without ipt). Leaf senescence was evaluated by measuring the chlorophyll content of excised or intact leaves exposed to the conditions, inducing senescence. Excised leaves were incubated in darkness in half-strength Hoagland's nutrient solution; with $10 \mu \mathrm{M}$ transzeatin riboside (ZR; Sigma-Aldrich) added to the incubation solution of the control line. Northern blot and CK content were analyzed for whole plants exposed to dark or heat stress to examine gene expression and CK content during dark- or heat-induced leaf senescence. Chlorophyll content was calculated based on the absorbance at 663 and $645 \mathrm{~nm}$ using the formulas described by Arnon (1949). A separate set 
of leaf samples were taken from the same plant at the same time of sampling for chlorophyll extraction, and fresh weight was measured immediately. Leaf chlorophyll content was expressed as milligrams per gram of fresh weight.

Two major forms of CK, transzeatin/zeatin riboside (Z/ZR) and isopentenyladenine/ adenosine (iP/iPA), were quantified by an indirect competitive enzyme-linked immunoabsorbent assay (ELISA). Extraction and quantification of hormones followed the method described by Setter et al. (2001) with some modifications (Wang et al., 2003). Briefly, samples were extracted in $80 \%(\mathrm{v} / \mathrm{v})$ methanol and were isolated with reverse phase $\mathrm{C}_{18}$ columns. Hydrophilic contaminants were washed out with $200 \mu \mathrm{L}$ of $20 \%$ solvent [ $20 \%$ methanol, $80 \%$ aqueous TEA (10 mm triethylamine, $\mathrm{pH} 3.5$ )]. The CK-containing fraction was eluted using $200 \mu \mathrm{L}$ of $30 \%$ solvent [ $30 \%$ methanol, $70 \%$ aqueous triethylamine (TEA)]. An indirect competitive ELISA was used for quantification of Z/ZR and iP/iPA as previously described by Setter et al. (2001). Monoclonal antibodies against Z/ZR and iP/iPA (Agdia, Elkhart, IN) were originally developed by Eberle et al. (1986).

Treatments. For the dark treatments, the second fully expanded leaves from the top of five tillers in each plant of the transgenic line were incubated in half-strength Hoagland's nutrient solution (Hoagland and Arnon, 1950) in petri dishes placed in darkness at $25^{\circ} \mathrm{C}$ for $30 \mathrm{~d}$; whole plants grown in soilfilled pots were exposed to darkness in a growth chamber at $20^{\circ} \mathrm{C}$ for $20 \mathrm{~d}$. For heat treatment, whole plants were exposed to $35^{\circ} \mathrm{C}$ for $7 \mathrm{~d}$ and were watered daily to prevent water deficit.

Statistical analysis. All physiological measurements and cytokinin analyses were performed in four replicated samples (plants). For light, dark, or temperature treatment, four replicated plants were examined for each treatment and each transgenic line. Data were analyzed using analysis of variance to determine treatment effects and difference between the control line and transgenic plants. The differences among lines and between treatments for a given line were separated using Fisher's protected least significant difference test at $P=0.05$.

\section{Results}

Confirmation of IPT transformation by PCR And GUS STAINING. A total of 142 SAG12-ipt and 138 HSP18-ipt putatively transformed plants were examined for ipt expression using PCR analysis. Over $95 \%$ of the plants exhibited positive PCR. Figure 2 illustrates ipt expression in nine transgenic lines containing HSP18-ipt and nine transgenic lines containing SAG12-ipt. GUS staining of roots was also performed to confirm plant transformation. Roots of transgenic plants were stained blue while nontransgenic plants had no blue staining in their roots (Fig. 2). Two selected transgenic lines were tested for transgene copy number. The transgene was present in single copy in SAG12-ipt and HSP18-ipt lines, as indicated by the quantity of DNA present in Southern blot analysis (Fig. 3).

EXPRESSION OF IPT IN SAG12-IPT AND HSP18-IPT PLANTS IN RESPONSE TO DARKNESS OR HEAT STRESS. Thirty-three lines of SAG12-ipt and 35 HSP18-ipt plants with desirable turf phenotype under nonstressed conditions were selected and examined for gene expression under darkness or heat stress at $35^{\circ} \mathrm{C}$. Northern blot analysis did not detect SAG12-ipt expression in plants exposed to normal light and temperature $\left(20{ }^{\circ} \mathrm{C}\right)$, but revealed that among the 33 SAG12-ipt transgenic plants, 58\% showed ipt expression when excised leaves were exposed to
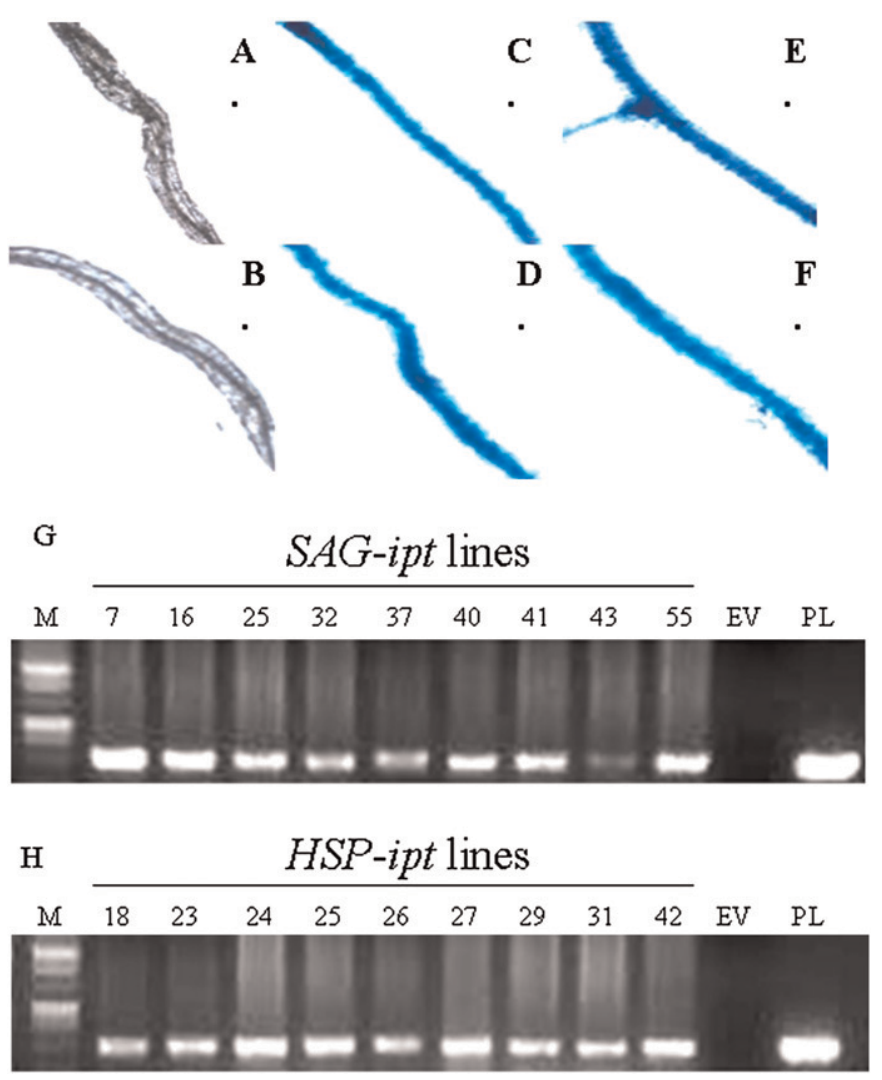

Fig. 2. Confirmation of transformation with GUS staining in the empty vector control line (A and B) and four HSP18-ipt lines (C-F) and PCR analysis in nine representative $S A$ G12-ipt line $(\mathbf{G})$ and nine representative HSP18-ipt lines $(\mathbf{H})$ of creeping bentgrass. $\mathrm{M}=$ marker, $\mathrm{EV}=$ plants transformed with empty vector, $\mathrm{PL}=$ plasmid containing the ipt gene.

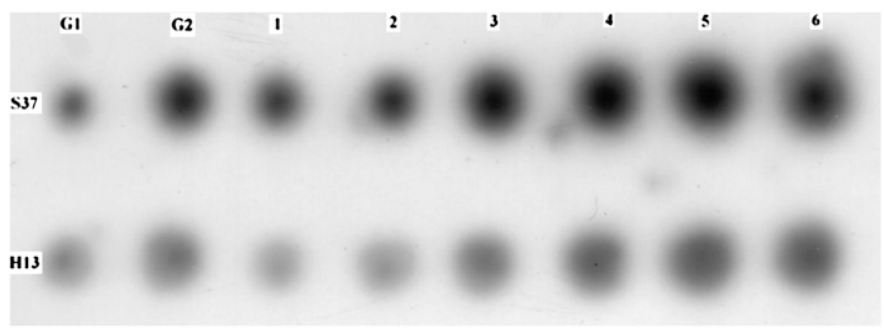

Fig. 3. Analysis of transgene copy number in two representative transgenic lines (SAG12-ipt transgenic line S37 and HSP18-ipt transgenic line H13) of creeping bentgrass. G1 = total DNA equal to one copy of creeping bentgrass total DNA, G2 = total DNA equal to two copies of creeping bentgrass total DNA; $1,2,3,4,5$, and $6=$ plastid DNA equal to one, two, three, four, five, and six copies of creeping bentgrass total DNA, respectively.

darkness for $20 \mathrm{~d}$ (Fig. 4A). For the 35 HSP18-ipt transgenic plants, 63\% showed ipt transcript when excised and subjected to heat stress at $35^{\circ} \mathrm{C}$ for $7 \mathrm{~d}$ (Fig. 4B). Whole plants of two SAG12-ipt lines, S37 and S43, were also exposed to darkness for $20 \mathrm{~d}$ or $35^{\circ} \mathrm{C}$ for $7 \mathrm{~d}$. Darkness and heat stress activated the expression of $S A G 12$-ipt, but the expression of ipt was more strongly induced by darkness than heat stress at $35^{\circ} \mathrm{C}$ for both SAG12-ipt lines (Fig. 4C).

The expression patterns of HSP18-ipt in whole plants exposed to different temperatures for different durations were examined in the transgenic line H31. Northern blot analysis of 
H31 plants treated at each temperature of $20,25,30,35$, and $40{ }^{\circ} \mathrm{C}$ for $2 \mathrm{~h}$ showed that ipt expression was strongly induced when temperature was elevated to 35 and $40{ }^{\circ} \mathrm{C}$ (Fig. 5A). With heat treatment duration, expression of ipt was detected at $2 \mathrm{~h}$ after $\mathrm{H} 31$ plants were exposed to $35^{\circ} \mathrm{C}$, and the expression level increased with treatment duration up to $12 \mathrm{~h}$ (Fig. 5B).

EVALUATION OF LEAF SENESCENCE AND CYTOKININ PRODUCTION IN $\boldsymbol{S} A G 12-I P T$ PLANTS EXPOSED TO DARKNESS. An excised leaf bioassay was performed to determine the response of nine SAG12-ipt transgenic lines to dark-induced leaf senescence. The third fully expanded leaves were clipped from each of the SAG12-ipt transgenic lines and the control line. Leaves were incubated in nutrient solution in the dark at $20^{\circ} \mathrm{C}$ in petri dishes for $30 \mathrm{~d}$. After $14 \mathrm{~d}$ in darkness, the control plants turned yellow while the transgenic leaves remained green; after $30 \mathrm{~d}$ in dark, the control leaves became completely chlorotic while the transgenic leaves still had some green spots (Fig. 6). Leaf chlorophyll content of all nine transgenic lines was significantly higher than control plants at $14 \mathrm{~d}$ of dark treatment, with two transgenic lines maintaining chlorophyll content twice that of the control and similar to the control leaves incubated with CK (Fig. 7).

Whole plants of nine SAG12-ipt transgenic lines were also incubated in darkness in growth chambers at $20{ }^{\circ} \mathrm{C}$ for $20 \mathrm{~d}$, and

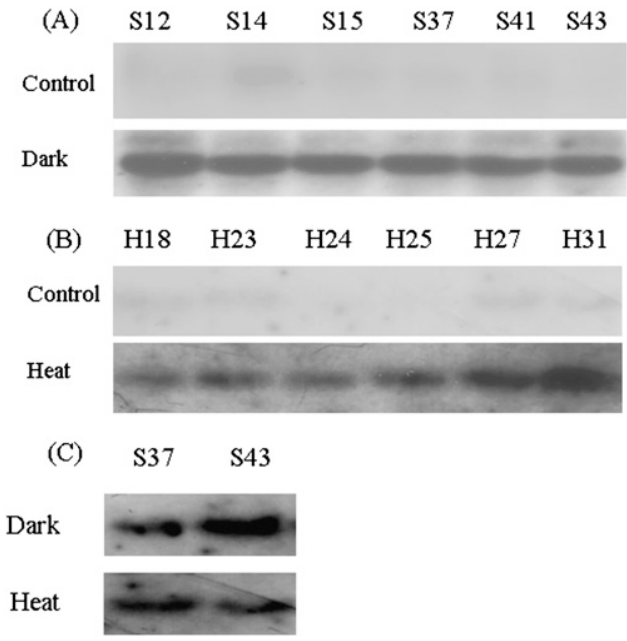

Fig. 4. Northern confirmation of ipt gene expression among different transgenic lines of creeping bentgrass. (A) $S A G 12$-ipt plants exposed to dark at $20^{\circ} \mathrm{C}$ for 20 d. (B) HSP18-ipt plants exposed to $35^{\circ} \mathrm{C}$ for $7 \mathrm{~d}$. (C) SAG12-ipt line S37 and S43 exposed to dark at $20^{\circ} \mathrm{C}$ or heat stress at $35^{\circ} \mathrm{C}$. Each lane was loaded with $10 \mu \mathrm{g}$ of RNA for each sample.

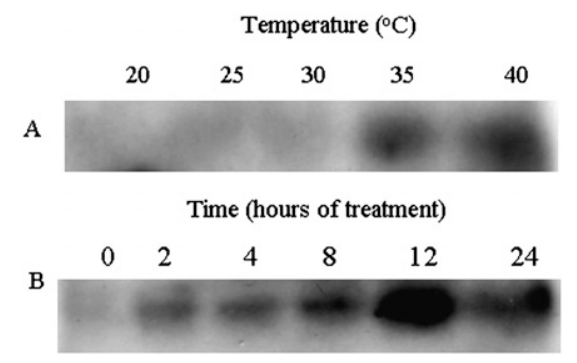

Fig. 5. Temperature and time course changes in ipt gene expression of a HSP18ipt transgenic line (H31) of creeping bentgrass. (A) Temperature course study of $\mathrm{H} 31$ treated for $2 \mathrm{~h}$ at $20,25,30,35$, and $40^{\circ} \mathrm{C}$. (B) Time course study of $\mathrm{H} 31$ treated at $35^{\circ} \mathrm{C}$ for $0,2,4,8,12$, and $24 \mathrm{~h}$. Each lane was loaded with 10 $\mu \mathrm{g}$ of RNA for each sample.

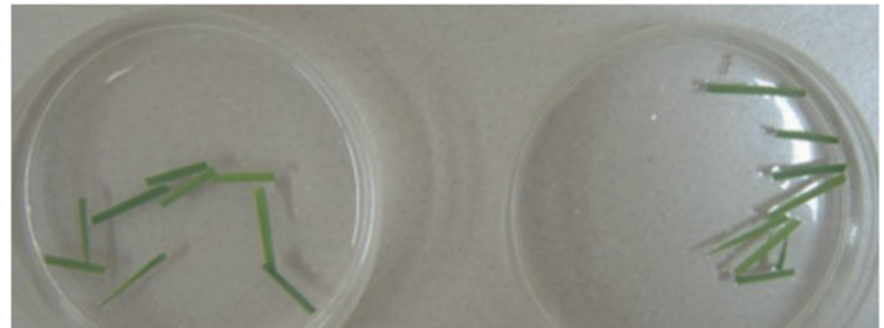

A

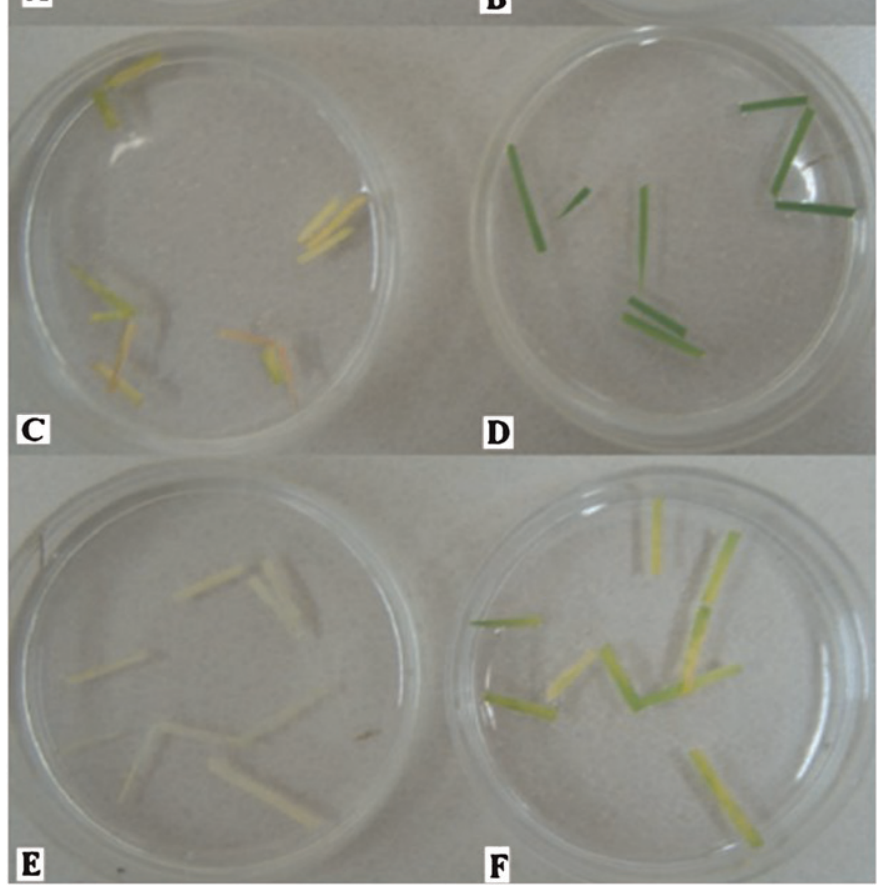

Fig. 6. Comparison of morphological differences between detached mature leaves of an empty vector control line (A, C, and E) and a SAG12-ipt transgenic line (S12) (B, D, and $\mathbf{F}$ ) of creeping bentgrass. Leaves were incubated in nutrient solution in the dark at $25{ }^{\circ} \mathrm{C}$ in petri dishes for $30 \mathrm{~d}$. (A and B) Leaves from the control line and SAG12-ipt line before dark treatment. After 2 weeks, leaves from the control line (C) turned yellow, while the SAG12-ipt transgenic leaves were still fresh green (D). After 1 month, leaves from the control line were all white-yellow $(\mathbf{E})$, while the transgenic leaves still had some green sections (F).

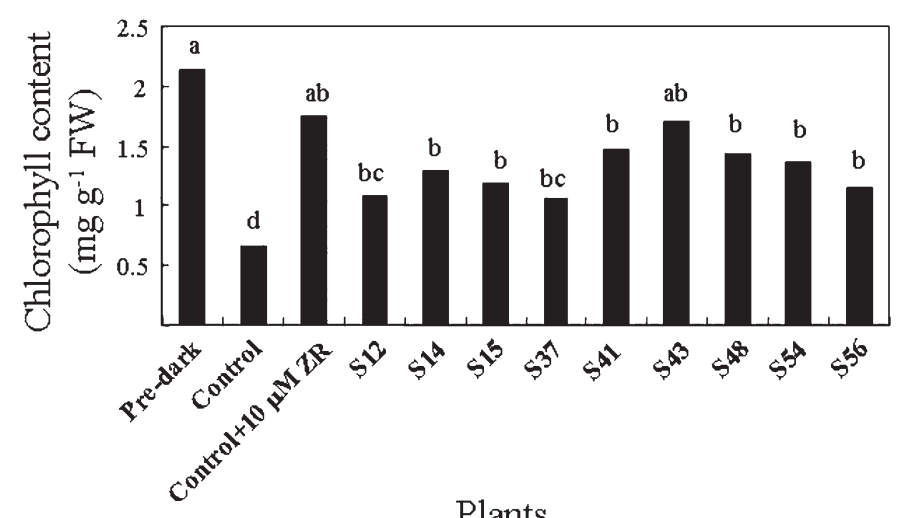

Fig. 7. Chlorophyll content of detached leaves from nine SAG12-ipt transgenic lines and control line of creeping bentgrass before (Pre-dark) and after incubation in the dark at $20^{\circ} \mathrm{C}$ for $14 \mathrm{~d}$. Control without (Control) or with ZR (Control $+10 \mu \mathrm{M}$ ZR). Columns marked with the same letters were not significantly different based on LSD test at $P=0.05$. 
chlorophyll content and CK content of leaves were determined. Chlorophyll content of all nine transgenic lines and the control decreased after $21 \mathrm{~d}$ of dark treatment, but the decline was less pronounced in all nine transgenic lines. Chlorophyll content of transgenic lines decreased an average of $23.1 \%$, whereas chlorophyll content of the control line declined $62.9 \%$ during dark treatment (Fig. 8). In six of the transgenic lines, the iP/iPA content remained the same or higher after dark treatment, whereas a significant reduction in $\mathrm{iP} / \mathrm{iPA}$ content occurred in the control line and in two transgenic lines (S15 and S48) after 20 d of dark treatment; nevertheless, the reduction was less in the two transgenic lines (19.1\% and 29.9\%) than in the control line (56.4\%) (Fig. 9). All nine transgenic lines had higher iP/iPA content than the control line at $20 \mathrm{~d}$ of treatment. No significant differences in Z/ZR content were detected between the control and transgenic lines during dark or heat treatment (data not shown).

HeAt STRESS RESPONSES OF HSP18-IPT TRANSGENIC PLANTS. When whole plants were incubated at $35{ }^{\circ} \mathrm{C}$ for $7 \mathrm{~d}$, chlorophyll content declined $38.2 \%$ in the control plants, but all nine transgenic plants were able to maintain chlorophyll content at the initial level (Fig. 10). All nine transgenic lines also had significantly higher chlorophyll content than the control line under heat stress, although no significant differences in chlorophyll content were detected at $20{ }^{\circ} \mathrm{C}$. The effects of heat stress and differences between the control and transgenic lines for iP/ iPA content followed the same pattern as chlorophyll content (Fig. 11). The iP/iPA content of the control line declined $52.5 \%$, whereas the transgenic plants maintained iP/iPA production and had higher iP/iPA content than the control plants under heat stress.

\section{Discussion}

Our study demonstrated that the transformation of SAG12-ipt resulted in the suppression of leaf senescence induced by dark or heat stress without the morphological abnormalities usually observed with constitutive promoters due to the autoregulation of $\mathrm{CK}$ synthesis (Gan and Amasino, 1995). The suppression of dark-induced leaf senescence, as demonstrated by the maintenance of higher chlorophyll content in the transgenic lines com- pared with the control line, could be associated with the greater production of iP/iPA in the transgenic plants. Luo et al. (2005) also found excised tomato leaf senescence to be delayed when $i p t$ was ligated to the AGPase $S 1$ promoter, which is active in the guard cells of the leaves. Li et al. (2004) found a significant delay in whole plant leaf senescence of perennial ryegrass (Lolium perenne) transformed by microprojectile bombardment with SEE-ipt. This delay in leaf senescence of grasses could have important economic consequences, especially after

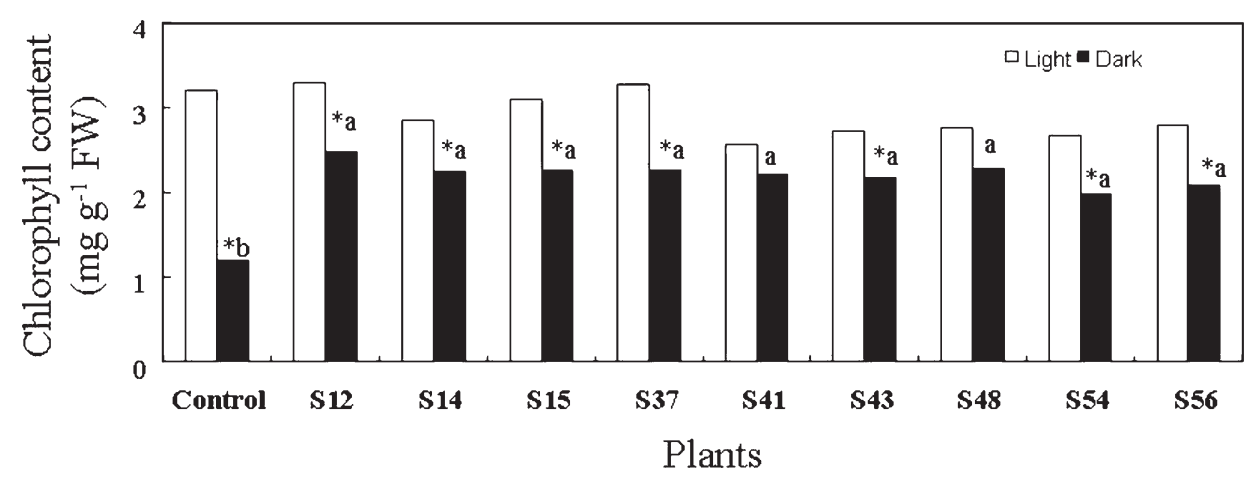

Fig. 8. Leaf chlorophyll content of whole plants grown of creeping bentgrass under light or in the dark at $20{ }^{\circ} \mathrm{C}$ for $20 \mathrm{~d}$. Columns marked with the same letters were not significantly different based on LSD test at $P=0.05$ for plants exposed to the dark; an asterisk indicates the difference between light and dark treatments.

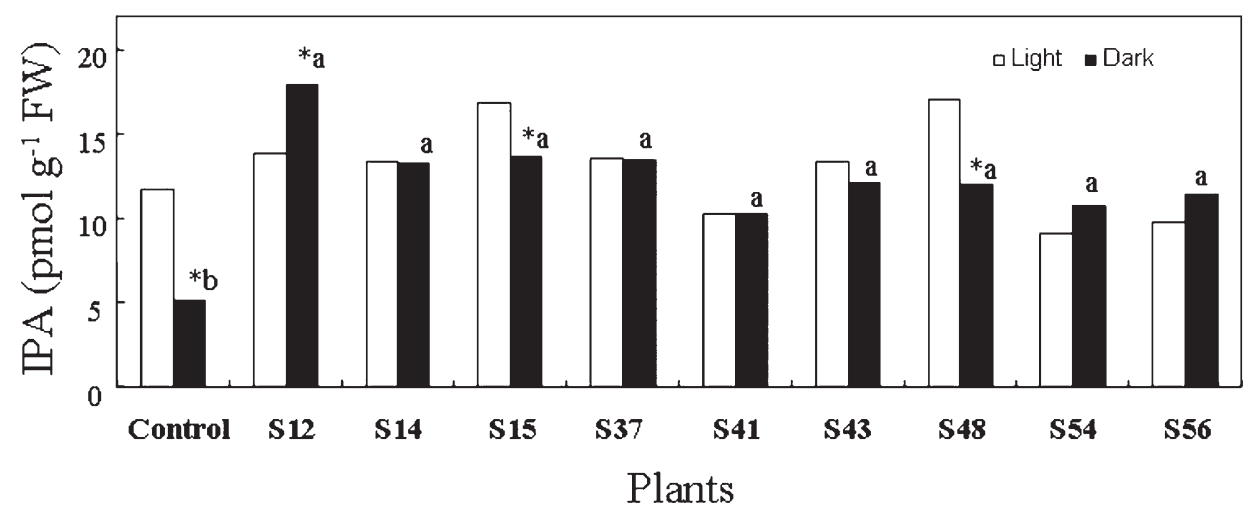

Fig. 9. Cytokinin content of whole plants of creeping bentgrass grown under light or in the dark at $20^{\circ} \mathrm{C}$ for $20 \mathrm{~d}$. Columns marked with the same letters were not significantly different based on LSD test at $P=0.05$ for plants exposed to the dark; an asterisk indicates the difference between light and dark treatments.

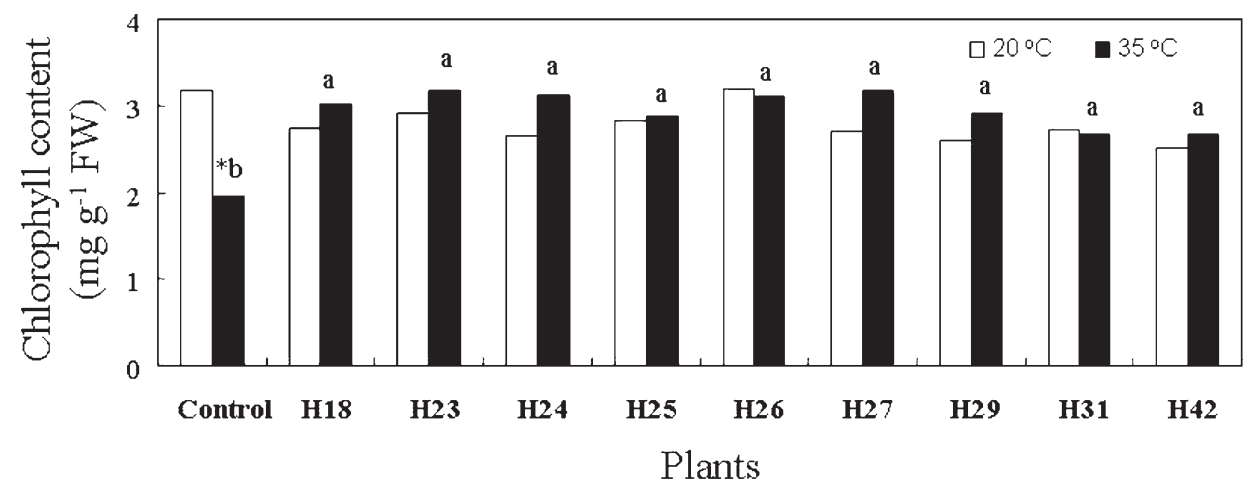

Fig. 10. Leaf chlorophyll content of HSP18-ipt whole plants of creeping bentgrass exposed to heat stress $\left(35^{\circ} \mathrm{C}\right)$ for $7 \mathrm{~d}$. Columns marked with the same letters were not significantly different based on LSD test at $P=0.05$ for plants exposed to heat stress; an asterisk indicates the difference between 20 and $35^{\circ} \mathrm{C}$. 


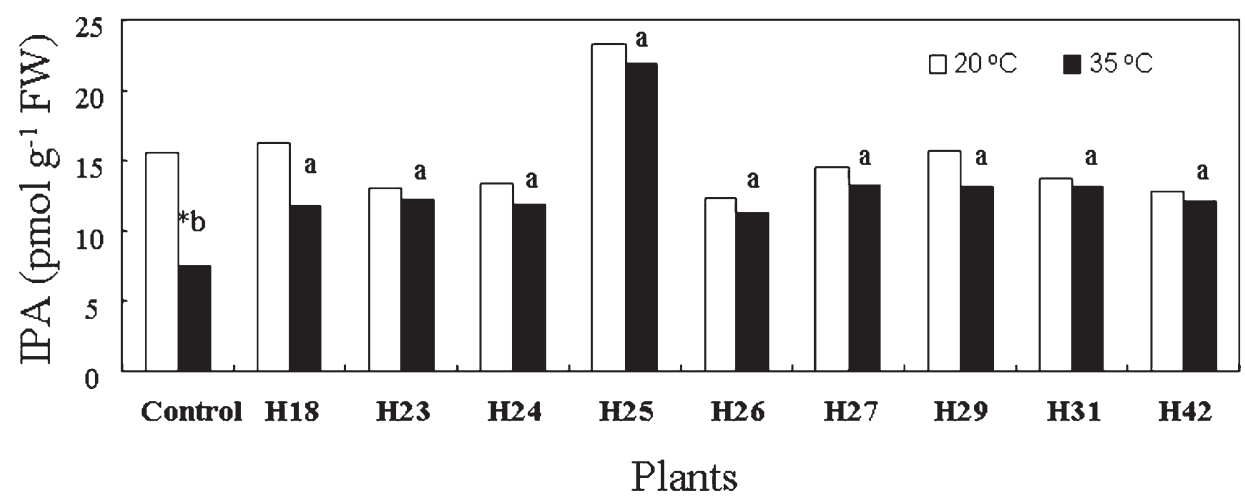

Fig. 11. Leaf isopentenyladenine (iP/iPA) content of HSP18-ipt whole plants of creeping bentgrass exposed to heat stress $\left(35^{\circ} \mathrm{C}\right)$ for $7 \mathrm{~d}$. Columns marked with the same letters were not significantly different based on LSD test at $P=0.05$ for plants exposed to heat stress; an asterisk indicates the difference between 20 and $35^{\circ} \mathrm{C}$.

active only in older leaves and generally not directly responsive to stress-mediated signals (Weaver et al., 1998). The heat stress response that we measured occurred after $7 \mathrm{~d}$ at $35^{\circ} \mathrm{C}$, probably as a result of the senescence induced by this treatment.

In summary, transgenic creeping bentgrass with SAG12-ipt or HSP18-ipt maintained chlorophyll content and delayed the leaf senescence typically induced by dark or heat stress. SAG12-ipt and HSP18ipt creeping bentgrass are potential new sources of grass germplasm with improved shade or heat tolerance. A field study is underway to

periods of stress. Hu et al. (2005) reported that tall fescue stayed green longer during the cooler temperatures of fall when transformed with a maize ubiquitin-ipt gene. Delayed leaf senescence is a desirable trait in perennial grass species used as turf or forage because maintaining green leaves provides an aesthetic function for turf and biomass production for forage grasses. Additional studies are needed to determine if the inhibition of leaf senescence in grass plants with ipt affects resource allocation to seeds, roots, and crowns.

We also created creeping bentgrass with the ipt gene ligated to a HSP promoter. To our knowledge, this is the first report of HSP18-ipt transformation in a perennial grass species, despite the importance of heat stress tolerance in cool-season grass species. Schmülling et al. (1989) were the first to show that with tobacco calluses, increased CK levels could be induced by heat treatment after transformation with ipt under the control of a drosophila (Drosophila melanogaster) HSP promoter. Smart et al. (1991) demonstrated that an HSP promoter from soybean (Glycine max) ligated to ipt could result in increased ipt expression after heat shock at $42{ }^{\circ} \mathrm{C}$ for $2 \mathrm{~h}$ and that this treatment led to higher levels of CK. Harding and Smigocki (1994) were the first to observe that transgenic tobacco with an HSP-ipt construct produced 2- to 4-fold higher levels of mRNA for small heat shock polypeptides and a wound-inducible glycine-rich protein, which may enhance heat tolerance.

Heat stress injury in plants results from a temperatureinduced decline in carbohydrate accumulation, leaf senescence, and free radical damage, leading to a loss of membrane integrity. One of the earliest biochemical consequences of heat stress injury is a decline in tissue CK content (Liu and Huang, 2005). Veerasamy et al. (2007) pretreated creeping bentgrass with $10 \mu \mathrm{M} Z R$ before heat stress and found that leaf chlorophyll content, photochemical efficiency $\left(\mathrm{F}_{\mathrm{v}} / \mathrm{F}_{\mathrm{m}}\right)$, and soluble protein content declined more slowly and protected plants from heat stress injury. The application of seaweed-based CK alleviated heat-induced decline in turfgrass quality, photochemical efficiency, and root viability in creeping bentgrass (Zhang and Ervin, 2008). Our results demonstrated that leaves of HSP18ipt plants exposed to heat stress treatment $\left(35^{\circ} \mathrm{C}\right.$ or higher) that had higher iPA content also exhibited lower electrolyte leakage and chlorophyll content compared with controls. Our SAG12-ipt plants also responded to heat stress, but not as strongly as the HSP18-ipt plants. SAG12 is known to be examine performance of SAG12-ipt and HSP18-ipt lines under natural environmental conditions.

\section{Literature Cited}

Arnon, D.I. 1949. Copper enzymes in isolated chloroplasts. Polyphenoloxidase in Beta vulgaris. Plant Physiol. 24:1-15.

Ausubel, F.M., R. Brent, R.E. Kingston, D.D. Moore, J.G. Seidman, J.A. Smith, and K. Struhl. 1995. Current protocols in molecular biology. Wiley, New York.

Chang, H., M.L. Jones, G.M. Banowetz, and D.G. Clark. 2003. Overproduction of cytokinins in petunia flowers transformed with PSAG12-IPT delays corolla senescence and decreases sensitivity to ethylene. Plant Physiol. 132:2174-2183.

Clark, D.G., C. Dervinis, J. Barrett, H. Klee, and M.L. Jones. 2004. Drought-induced leaf senescence and horticultural performance of $\mathrm{P}_{\mathrm{SAG12}}-I P T$ petunias. J. Amer. Soc. Hort. Sci. 129:93-99.

Dellaporta, S.L., J. Woods, and J.B. Hicks. 1983. A plant minipreparation, version II. Plant Mol. Biol. Rpt. 1:19-21.

Dong, S. and R. Qu. 2005. High efficiency transformation of tall fescue with Agrobacterium tumefaciens. . Plant Sci. 168:1453-1458.

Eberle, J., A. Arnscheidt, D. Klix, and E.W. Weiler. 1986. Monoclonal antibodies to plant growth regulators. III. Zeatin riboside and dihydrozeatin riboside. Plant Physiol. 81:516-521.

Gan, S. and R.M. Amasino. 1995. Inhibition of leaf senescence by autoregulated production of cytokinin. Science 270:1986-1988.

Gan, S. and R.M. Amasino. 1996. Cytokinins in plant senescence: From spray and play to clone and play. Bioessays 18:557-565.

Harding, S.A. and A.C. Smigocki. 1994. Cytokinins modulate stress response genes in isopentenyl transferase-transformed Nicotiana plumbaginifolia plants. Physiol. Plant. 90:327-333.

Hare, P.D., W.A. Gress, and J. van Staden. 1997. The involvement of cytokinins in plant responses to environmental stress. Plant Growth Regulat. 23:79-103.

Hewelt, A., E. Prinsen, J. Schell, H. Van Onckelen, and T. Schmülling. 1994. Promoter tagging with a promoterless ipt gene leads to cytokinin-induced phenotypic variability in transgenic tobacco plants: Implications of gene dosage effects. Plant J. 6:879-891.

Hoagland, D.R. and D.I. Arnon. 1950. The water-culture method for growing plants without soil. California Agr. Expt. Sta. Circ. 347.

Hu, Y., W. Jia, Y. Wang, Y. Zhang, L. Yang, and Z. Lin. 2005. Transgenic tall fescue containing the Agrobacterium tumefaciens ipt gene shows enhanced cold tolerance. Plant Cell Rep. 23:705-709.

Huang, B. 2004. Recent advances in drought and heat stress physiology of turfgrass: A review. Acta Hort. 661:185-192.

Huynh, N.L., T. VanToai, J. Streeter, and G. Banowetz. 2005. Regulation of flooding tolerance of SAG12:ipt Arabidopsis plants by cytokinin. J. Expt. Bot. 56:1397-1407. 
Jefferson, R.A., T.A. Kavanagh, and M.W. Bevan. 1987. GUS fusions: $\beta$-Glucuronidase as a sensitive and versatile gene fusion marker in higher plants. EMBO J. 13:3901-3907.

Khodakovskaya, M., Y. Li, J. Li, R. Vanková, J. Malbeck, and R. McAvoy. 2005. Effects of cor15a-IPT gene expression on leaf senescence in transgenic Petunia $\times$ hybrida and Dendranthema $\times$ grandiflorum. J. Expt. Bot. 56:1165-1175.

Koh, K.J., G.E. Bell, D.L. Martin, and N.R. Walker. 2003. Shade and airflow restriction effects on creeping bentgrass golf greens. Crop Sci. 43:2182-2188.

Li, Q., P.R.H. Robson, A.J.E. Bettany, L.S. Donnison, H. Thomas, and I.M. Scott. 2004. Modification of senescence in ryegrass transformed with IPT under the control of a monocot senescence-enhanced promoter. Plant Cell Rep. 22:816-821.

Liu, X. and B. Huang. 2005. Root physiological factors involved in cool-season grass response to high soil temperature. Environ. Exp. Bot. 53:233-245.

Luo, Y., T.J. Gianfagna, H.W. Janes, B. Huang, Z. Wang, and J. Xing. 2005. Expression of the ipt gene with the AGPase s1 promoter in tomato results in unbranched roots and delayed leaf senescence. Plant Growth Regulat. 47:47-57.

McCabe, M.S., L.C. Garratt, F. Schepers, W.J.R.M. Jordi, G.M. Stoopen, E. Davelaar, J.H.A. van Rhijn, B.J. Power, and R. Michael. 2001. Effects of $P_{\mathrm{SAG} 12}-I P T$ gene expression on development and senescence in transgenic lettuce. Plant Physiol. 127:505-516.

McCabe, M.S., U. Mohapatra, F. Schepers, K. van Dun, J.B. Power, and M. Davey. 1998. Delayed senescence in transgenic lettuce using an autoregulated ipt gene. J. Expt. Bot. Suppl. 49:49.

Medford, J.I., R. Horgan, Z. El-Sawi, and H.J. Klee. 1989. Alterations of endogenous cytokinins in transgenic plants using a chimeric isopentenyl transferase gene. Plant Cell 1:403-413.

Murashige, T. and F. Skoog. 1962. A revised medium for rapid growth and bioassays with tobacco tissue cultures. Physiol. Plant. 15:473-497.

Nguyen, T.D., P. Chen, W. Huang, H. Chen, D. Johnson, and J.R. Polansky. 1998. Gene structure and properties of an olfactomedinrelated glycoprotein, TIGR, cloned from glucocorticoid-induced trabecular meshwork cells. J. Biol. Chem. 273:6341-6350.

Rivero, R., M. Kojima, A. Gepstein, H. Sakakibara, R. Mittler, S. Gepstein, and E. Blumwald. 2007. Delayed leaf senescence induces extreme drought tolerance in a flowering plant. Proc. Natl. Acad. Sci. USA 104:19631-19636.

Schmülling, T., S. Beinsberger, J. De Greef, J. Schell, H. Van Onckelen, and A. Spena. 1989. Construction of a heat-inducible chimeric gene to increase the cytokinin content in transgenic plant tissue. FEBS Lett. 249:401-406.

Setter, T.L., B.A. Flannigan, and J. Melkonian. 2001. Loss of kernel set due to water deficit and shade in maize: Carbohydrate supplies, abscisic acid, and cytokinins. Crop Sci. 41:1530-1540.

Smart, C.M., S.R. Scofield, M.W. Bevan, and T.A. Dyer. 1991. Delayed leaf senescence in tobacco plants transformed with $\mathrm{tmr}$, a gene for cytokinin production in Agrobacterium. Plant Cell 3:647656.

Smigocki, A.C. 1991. Cytokinin content and tissue distribution in plants transformed by a reconstructed isopentenyl transferase gene. Plant Mol. Biol. 16:105-115.

Sykorova, B., G. Kuresova, S. Daskalova, M. Trcova, K. Hoyeriva, I. Raimanova, V. Motyka, A. Travnickova, M. Elliott, and M. Kaminel. 2008. Senescence-induced ectopic expression of the A.tumefaciens ipt gene in wheat delays leaf senescence, increases cytokinin content, nitrate influx and nitrate reductase activity, but does not affect grain yield. J. Expt. Bot. 59:377-387.

Takahashi, T. and Y. Komeda. 1989. Characterization of two genes encoding small heat-shock proteins in Arabidopsis thaliana. Mol. Gen. Genet. 219:365-372.

Van Loven, K., S.E.I. Beinsberger, R.L.M. Valcke, H.A. Van Onckelen, and H.M.M. Clijsters. 1993. Morphometric analysis of the growth of Phsp70-ipt transgenic tobacco plants. J. Expt. Bot. 44:1671-1678.

Veerasamy, M., Y. He, and B. Huang. 2007. Leaf senescence and protein metabolism in creeping bentgrass exposed to heat stress and treated with cytokinins. J. Amer. Soc. Hort. Sci. 132:467472.

Wang, Z., B. Huang, and Q. Xu. 2003. Effects of exogenous abscisic acid on drought resistance in two Kentucky bluegrass cultivars. J. Amer. Soc. Hort. Sci. 128:36-41.

Weaver, L.M., S. Gan, B. Quirino, and R.M. Amasino. 1998. A comparison if the expression patterns if several senescence-associated genes in response to stress and hormone treatment. Plant Mol. Biol. 37:455-469.

Yu, T., D.Z. Skinner, G. Liang, H.N. Trick, B. Huang, and S. Muthukrishnan. 2000. Agrobacterium-mediated transformation of creeping bentgrass using GFP as a reporter gene. Hereditas 133:229233.

Zhang, X. and E.H. Ervin. 2008. Impact of seaweed extract-based cytokinins and zeatin riboside on creeping bentgrass heat tolerance. Crop Sci. 48:364-370. 